Commentary

\title{
Social Navigation and the Refugee Crisis: Traversing "Archipelagos" of Uncertainty
}

\author{
Melissa Wall \\ Department of Journalism, California State University - Northridge, Northridge, CA 91330, USA; \\ E-Mail: melissawall@gmail.com
}

Submitted: 18 June 2019 | Accepted: 18 June 2019 | Published: 28 June 2019

\begin{abstract}
This reflection considers the thematic issue "Refugee Crises Disclosed: Intersections between Media, Communication and Forced Migration Processes" through the lens of social navigation which takes into account the fluidity and uncertainty of the refugee and forced migrant condition whether in flight, emplaced, or at a temporary stopping point. Refugees who are able to "read" their social environment will be more successful in developing practices to navigate through unpredictable migration processes, including responding to information uncertainty. Yet even as some of the displaced adapt, other actors - particularly those part of the refugee regime-are also operating in unstable conditions such that the actions of refugees/forced migrants may in turn keep the circumstances of those purporting to help also in flux.
\end{abstract}

\section{Keywords}

belonging; digital environment; information precarity; migrant; refugee; social navigation; uncertainty

\section{Issue}

This commentary is part of the issue "Refugee Crises Disclosed: Intersections between Media, Communication and Forced Migration Processes", edited by Vasiliki Tsagkroni (Leiden University, The Netherlands) and Amanda Alencar (Erasmus University Rotterdam, The Netherlands).

(C) 2019 by the author; licensee Cogitatio (Lisbon, Portugal). This article is licensed under a Creative Commons Attribution 4.0 International License (CC BY).

This thematic issue on "Refugee Crises Disclosed" provides a window into the constellation of adaptive tactics enacted by refugees and forced migrants as they respond to both "radical and protracted uncertainty" (Horst \& Grabska, 2015, p. 1). While 21st century social life in general has been described as insecure, liquid and marked by risk, the ways refugees and forced migrants experience such conditions is further shaped by the reasons for their flight (often violent political or economic conflict) as well as the nature of their movement in terms of sudden, often unplanned dislocation. In response to these uncertainties, refugees deploy practices of social navigation or the ways "people act in difficult or uncertain circumstances... [as] they disentangle themselves from confining structures" (Vigh, 2009, p. 419). The concept of social navigation "directs our attention to both the way people engage in the world and the way they move toward positions they perceive as being better than their current location" and is intended to capture the flows of actions across ever changing social environments (Vigh, 2009, p. 432). In sum, social navigation consists of dynamic movements carried out by actors "within a moving environment" or what Vigh (2009) calls "motion squared" (p. 420).

A common thread in this special issue's collection of studies is the documentation of the ways refugees and forced migrants engage in social navigation of displacement. Some refugees enact this navigation using "visão" (vision), an ability to read "the wider social environment [with] the poise and cunning required for successful living" (Archambault, 2013, pp. 89-90). We see this in Von Burg's (2019) consideration of the ongoing landings of refugees on Lampedusa, where those making unsanctioned arrivals must navigate their legal status as they aim for the perceived safety of Europe. As with most refugees, their wayfaring is complicated by the "archipelago" of actors and actants found in the transnational migration process (Triandafyllidou, 2019, 
p. 1). Here, refugees' social navigation tactics include determining whether to exert independence as they seek a new future or submit to dependence by placing themselves solely within the care of the refugee system.

Even for those who get off islands both real and metaphoric, their navigation must remain fluid because reaching a destination is never really "final" as dynamic changes in policies, who carries them out and how they do so continue upon arrival at the next depot wherever that may be (Triandafyllidou, 2019; Van Neste-Gottignies \& Mistiaen, 2018). As Alencar and Tsagkroni (2019) find, for example, refugees granted asylum in the Netherlands come to understand that navigating new lives in the context of Western Europe is an ongoing process of adaptation and negotiation, one in which they volunteer, visit cultural sites and carry out observations in public spaces as they place themselves into dialogue with their social environment and networks, creating their own trajectories toward the expectations of official integration, which are themselves subject to ever-changing social forces. As refugees move within social environments, those environments are also in motion. Such is also the case of refugees in New Zealand examined by Marlowe (2019) who engage in political activities through transnational networks with goals of remaking the countries they have fled from, and, in taking such action, potentially remaking themselves. Their navigation processes enable them to "develop different forms of agency" unavailable or even unimaginable to them in their pre-exile lives (Triandafyllidou, 2019, p. 6).

Finally, across the various cases presented here, one notable uncertainty of migration consists of "information precarity" (Wall, Otis Campbell, \& Janbek, 2017), a condition in which access to information is limited leaving those who experience it "vulnerable to misinformation, stereotyping, and rumors that can affect their economic and social capital" (p. 240). Increasingly, this condition is navigated by refugees in the digital environment (see Alencar, 2018; Dekker, Engbersen, Klaver, \& Vonk, 2018; Gillespie, Osseiran, \& Cheesman, 2018; Leurs \& Smets, 2018; Witteborn, 2015). This issue's scholars demonstrate how refugees challenge information and emotional deprivations by engaging in online spaces that provide a means to enact a present and/or imagine a future of belonging (Marlowe, Bartley, \& Collins, 2017). This may encompass political belonging launched from within new homelands such as Marlowe (2019) describes as well as affective belonging to new and old networks as they use social media platforms to elicit emotional support (Kneer, Van Eldik, Jansz, Eischeid, \& Usta, 2019), as a strategy to build self-esteem (Van Eldik, Kneer, \& Jansz, 2019) or for staying in touch with culture from their homeland (Neag, 2019). Yet for other refugees and migrants the digital space can facilitate violent threats (Gabdulhakov, 2019); in these cases, migrants may use social navigational tactics such as self-protection through silence and isolation. In sum, refugees and forced migrants are constantly negotiating with their social environments whether online or offline, sometimes creating resistant visions of their futures to liberate themselves from the present. Ultimately, as Horst and Grabska (2015) argue, responding to uncertaintyviewed here through social navigation practice-opens up unexpected new ways of acting in the world.

\section{Acknowledgments}

Thank you to Amanda Alencar and Vasiliki Tsagkroni for shepherding this issue to completion.

\section{Conflict of Interests}

The author declares no conflict of interests.

\section{References}

Alencar, A. (2018). Refugee integration and social media: A local and experiential perspective. Information, Communication \& Society, 21(11), 1588-1603.

Alencar, A., \& Tsagkroni, V. (2019). Prospects of refugee integration in the Netherlands: Social capital, information practices and digital media. Media and Communication, 7(2), 184-194.

Archambault, J. S. (2013). Cruising through uncertainty: Cell phones and the politics of display and disguise in Inhambane, Mozambique. American Ethnologist, 40(1), 88-101.

Dekker, R., Engbersen, G., Klaver, J., \& Vonk, H. (2018). Smart refugees: How Syrian asylum migrants use social media information in migration decision-making. Social Media + Society, 4(1). https://doi.org/10. $1177 / 2056305118764439$

Gabdulhakov, R. (2019). In the bullseye of vigilantes: Mediated vulnerabilities of Kyrgyz labour migrants in Russia. Media and Communication, 7(2), 230-241.

Gillespie, M., Osseiran, S., \& Cheesman, M. (2018). Syrian refugees and the digital passage to Europe: Smartphone infrastructures and affordances. Social Media + Society, 4(1). https://doi.org/10.1177/ 2056305118764440

Horst, C., \& Grabska, K. (2015). Introduction: Flight and exile-Uncertainty in the context of conflict-induced displacement. Social Analysis, 59(1), 1-18.

Kneer, J., Van Eldik, A., Jansz, J., Eischeid, S., \& Usta, M. (2019). With a little help from my friends: Peer coaching for refugee adolescents and the role of social media. Media and Communication, 7(2), 264-274.

Leurs, K., \& Smets, K. (2018). Five questions for digital migration studies: Learning from digital connectivity and forced migration in (to) Europe. Social Media + Society, 4(1). https://doi.org/10.1177/ 2056305118764425

Marlowe, J. (2019). Social media and forced migration: The subversion and subjugation of political life. Media and Communication, 7(2), 173-183.

Marlowe, J. M., Bartley, A., \& Collins, F. (2017). Digital 
belongings: The intersections of social cohesion, connectivity and digital media. Ethnicities, 17(1), 85-102.

Neag, A. (2019). Board games as interview tools: Creating a safe space for unaccompanied refugee children. Media and Communication, 7(2), 254-263.

Triandafyllidou, A. (2019). The migration archipelago: Social navigation and migrant agency. International Migration, 57(1), 5-19.

Van Eldik, A., Kneer, J., \& Jansz, J. (2019). Urban \& online: Social media use among adolescents and sense of belonging to a super-diverse city. Media and Communication, 7(2), 242-253.

Van Neste-Gottignies, A., \& Mistiaen, V. (2018). Une communication peu visible: I'Agence fédérale Belge pour l'accueil des demandeurs d'asile, les centres ouverts et le retour volontaire. Langage et societe, 3, 51-74.

Vigh, H. (2009). Motion squared: A second look at the concept of social navigation. Anthropological Theory, 9(4), 419-438.

Von Burg, A. (2019). Citizenship islands: The ongoing emergency in the Mediterranean Sea. Media and Communication, 7(2), 218-229.

Wall, M., Otis Campbell, M., \& Janbek, D. (2017). Syrian refugees and information precarity. New Media \& Society, 19(2), 240-254.

Witteborn, S. (2015). Becoming (im)perceptible: Forced migrants and virtual practice. Journal of Refugee Studies, 28(3), 350-367.

\section{About the Author}

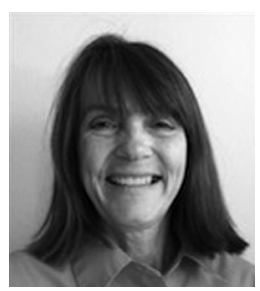

Melissa Wall is Professor of Journalism at California State University - Northridge. She has been a Fulbright scholar at Notre Dame University in Lebanon and an Open Society Academic Fellow at the Mohyla School of Journalism in Ukraine. Her research on refugees appears in New Media \& Society, Sage Handbook of Media and Migration, The Handbook of Diasporas, Media and Culture, The Washington Post, The Hill and other news sites. Her books include Citizen Journalism: Practices, Propaganda, Pedagogy, Citizen Journalism: Valuable, Useless or Dangerous? and forthcoming Mapping Citizen and Participatory Journalism: In Newsrooms, Classrooms and Beyond. 